\title{
A FinTech-innovációk ösztönzésének szabályozói eszközei: Innovation Hub és Regulatory Sandbox a nemzetközi gyakorlatban*
}

\author{
Fáykiss Péter - Papp Dániel - Sajtos Péter - Törös Ágnes
}

Tanulmányunkban azt vizsgáljuk, hogy szabályozói oldalról milyen, pénzügyi stabilitási célokat is szem előtt tartó eszközökkel ösztönözhetők a FinTech-innovációk. A FinTech-innovációk mikro-, makroprudenciális, illetve fogyasztóvédelmi szempontú lehetőségeinek és kockázatainak áttekintését követően bemutatjuk, hogy milyen szabályozói válaszok merülhetnek fel a FinTech-jelenség adta kihívásokra, és milyen szabályozói eszközöket alkalmaznak a nemzetközi gyakorlatban. Ezen gyakorlatokat jogi megvalósítás tekintetében elemezzük, kitérve azok különbözőségeire és hasonlóságaira. Végül röviden ismertetjük a FinTech-innovációkat ösztönző hazai szabályozói kezdeményezéseket. A nemzetközi példák vizsgálata arra mutat rá, hogy nem létezik általánosan hatékony, minden geopolitikai sajátosságot kielégítö, uniformizált megoldás: a koncepciók kialakításakor tekintettel kell lenni az adott ország pénzügyi közvetítő rendszerének, jogi környezetének sajátosságaira és a pénzügyi kultúra szintjére is.

Journal of Economic Literature (JEL) kódok: K2, G28, F39

Kulcsszavak: pénzügyi stabilitás, fintech, innovation hub, regulatory sandbox

\section{Bevezetés}

A 20. század végéig a pénzügyi rendszer élen járt a technológiai újítások alkalmazásában, ez azonban a 21. század elején már kevésbé volt jellemző. A bankrendszer az 1960-as évektől kezdve jelentős mértékben támaszkodott az új technológiai megoldásokhoz kapcsolódó újításokra: az elmúlt évtizedek meghatározó fejlesztései közé tartozó bankkártya, ATM és az elszámolások lebonyolítására használt elektronikus rendszer mind jól példázza a bankrendszer nyitottságát az innovációkra, de a tőke-

\footnotetext{
* A jelen kiadványban megjelenő írások a szerzők nézeteit tartalmazzák, ami nem feltétlenül egyezik a Magyar Nemzeti Bank hivatalos álláspontjával.

Fáykiss Péter a Magyar Nemzeti Bank igazgatója. E-mail: faykissp@mnb.hu Papp Dániel a Magyar Nemzeti Bank jogásza. E-mail: pappd@mnb.hu

Sajtos Péter a Magyar Nemzeti Bank junior elemzője. E-mail: sajtosp@mnb.hu

Tórös Ágnes a Magyar Nemzeti Bank közgazdasági elemzője. E-mail: torosa@mnb.hu

A magyar nyelvű kézirat első változata 2018. március 28-án érkezett szerkesztőségünkbe.

DOI: http://doi.org/10.25201/HSZ.17.2.4367
} 
piaci és biztosítási szektorban is hasonló szemlélet volt a meghatározó (Arner et al. 2016; MNB 2017). Az utóbbi években azonban az információs és kommunikációs technológiák ugrásszerű fejlődése és alkalmazása innovációk teljes sorát tette nélkülözhetetlenné a gazdaság különböző ágazataiban. A digitális technológiák széles körü felhasználása folyamatosan beépül a mindennapokba, a társadalom számára pedig lassan alapvető fontosságú, hogy a szolgáltatásokat digitális csatornákon keresztül is igénybe tudja venni, és ezen trend alól a pénzügyi termékek és szolgáltatások sem tudják kivonni magukat. Amellett azonban, hogy a technológiai újítások számos más szektor szereplőinek múködésébe beépültek, a pénzügyi intézmények és különösen a bankrendszer nem tudta megvalósítani ezek mély integrációját a napi múködésbe (EY 2016).

A 2008-as válságot követően több tényező is hátráltatta a pénzügyi szektort a digitális forradalom adta lehetőségek mélyebb kihasználásában. Egyrészt a válság hatására a nemteljesítő hitelek aránya dinamikusan nőtt, ami az értékvesztéseken keresztül rontotta a bankok tőkehelyzetét, illetve a válságkezelés jelentős humánerőforrásokat is lekötött. Másrészt a válság hatására kialakult tartósan alacsony kamatkörnyezet nyomást helyezett a bankok bevételi oldalára, ami hosszabb távon jövedelmezőségi kihívásokat jelenthet változatlan költségszint mellett. Végül a válság hatására a fogyasztók bankrendszerbe vetett bizalma is csökkent (Stevenson - Wolfers 2011), valamint a szabályozói elvárások is érdemben növekedtek. Ezen tényezők együttes hatására a bankok és egyéb pénzügyi szereplők jelentős kihívással szembesültek a profittermelés helyreállítása során.

A technológiai újítások a fokozódó versenyen keresztül alapjaiban változtathatják meg a pénzügyi szektorban aktív szereplők üzleti modelljeit, olyan kockázatokat indukálva a rendszerbe, melyek aktív szabályozói kontrollja nélkülözhetetlen. A szabályozó szerepét földrajzi dimenzióban is érdemes vizsgálni, mivel eltérő geopolitikai rendszert alkot mind a magyar, mind az európai uniós, mind pedig a nemzetközi szabályrendszer, így adott esetben egy nemzetközi technológiai vállalat tekintetében nagyfokú harmonizációs igény keletkezik. A nagy technológiai vállalatok (BigTech) és startupok múködése nagymértékben támaszkodik a digitalizációra és a különféle online platformokra, így ezen piaci szereplők alacsony költségszinttel képesek múködni, aktivitásuk árleszorító hatással járhat. Ennek következtében az inkumbens intézményeknek ${ }^{1}$ elsősorban költségoldalon indokolt alkalmazkodni (European Parliament 2017), mivel esetükben a magas múködési költségek továbbra is globális problémát jelentenek (EY 2016).

Az új technológiai megoldásokkal lehetőség nyílik arra, hogy a pénzügyi szektor szereplői érdemben javítsák költséghatékonyságukat. Emellett az új ötletek korai alkalmazása akár tartós versenyelőnyt is biztosíthat, valamint egy, a gazdaság ver-

\footnotetext{
${ }^{1}$ Inkumbens intézmény alatt a piacon már jelenlevő, hagyományos pénzügyi intézményeket értjük.
} 
senyképessége szempontjából is jelentős előnyökkel bíró megoldás számos külső érintett magatartására is befolyással lehet. Amennyiben a szabályozó hatóság is felismeri ezen előnyöket, a fejlesztéseket a szabályozói környezet célzott változása is támogathatja, ami tovább bővítheti az elsők között reagálók lehetőségeit, fenntartva a kezdeti versenyelőnyüket (Lee - Teo 2015). A korai alkalmazásból eredő előnyök kiaknázása azért is fontos, mert üzleti oldalról kedvező az inkumbens intézmények számára, hogy a fejlett országokban a fogyasztók jelentős része ragaszkodik a megszokott bankjához, ami egyrészt elősegítheti a bankok FinTech-cégekkel megvalósuló együttműködését, másrészt a meglévő jelentős ügyfélbázis támogathatja a jövőbeli fejlesztési lehetőségek azonosítását és kiaknázását (McKinsey 2016; FSB 2017). Ezen túlmenően a kereskedelmi bankok szerepe a pénzteremtésben és a pénzügyi közvetítőrendszerben szintén versenyelőnyt jelent a nem inkumbens vállalatokkal szemben (MNB 2017).

Jelen tanulmányunkban azt vizsgáljuk, hogy szabályozói oldalról milyen, pénzügyi stabilitási célokat is szem előtt tartó eszközökkel ösztönözhetők a FinTech-innovációk. Először áttekintjük, hogy milyen lehetőségekkel és potenciális kockázatokkal járhatnak ezen innovációk mikroprudenciális, makroprudenciális, illetve fogyasztóvédelmi szempontból; majd bemutatjuk, hogy milyen lehetséges szabályozói válaszok merülhetnek fel a FinTech-jelenség adta kihívásokra, és milyen szabályozói eszközöket alkalmaznak a nemzetközi gyakorlatban. Ezt követően a jogi megvalósítás tekintetében mélyebben is elemezzük a szabályozói megoldásokat, kitérve azok különbözőségeire és hasonlóságaira. Végül röviden ismertetjük a FinTech-innovációkat ösztönző hazai szabályozói kezdeményezéseket is.

\section{A FinTech-innovációkban rejlő lehetőségek és kockázatok}

A szakirodalomban jelenleg még nincs egy teljesen egységes, széles körben elfogadott definíció az elmúlt néhány évben a pénzügyi innovációk tekintetében egyre elterjedtebb FinTech (financial technology) fogalomra vonatkozóan, általában az innovatív technológia pénzügyi szolgáltatások keretében történő felhasználását érthetjük alatta (Nicoletti 2017; MNB 2017). A Financial Stability Board (FSB) jelentése alapján olyan technológia vezérelt pénzügyi innováció, amely új üzleti modelleket, alkalmazásokat vagy termékeket eredményezhet, amelyek érdemi hatással lehetnek a pénzügyi intézményekre, a pénzügyi szolgáltatásokra és a pénzügyi piacokra (FSB 2017; MNB 2017). Tekintettel arra, hogy az innováció a pénzügyi szektorban korábban is jellemző volt, a technológiai fejlődés mentén a FinTech-jelenségnek több fázisa is azonosítható. Az első időszak megjelenése az 1800 -as évek második felére tehető a távíró és a későbbiekben a telefon elterjedésével. A 20. század második felében tapasztalt, az információs technológia fejlődése következtében eszközölt fejlesztéseket a FinTech 2.0 kifejezéssel is lehet illetni (pl. ATM-ek megjelenése, telebank), míg az elmúlt években zajló, felgyorsult ütemü, jelen tanulmány tárgyát 
képező technológiai innovációkat FinTech 3.0 néven is említi a szakirodalom (Arner et al. 2016).

Az aktuálisan megfigyelhető FinTech-innovációk lehetnek hatékonyságnövelő típusú („,efficiency innovation”), fenntartó típusú (,sustaining technology”) és felforgató típusú („disruptive technology”) innovációk (Christensen 1997). A hatékonyságnövelő újitások egy, már létező technológiát fejlesztenek tovább, többnyire a meglévő infrastruktúrára épülö, annak hatékonyságát javító megoldások tartoznak ide, legyen szó akár a fizetési lehetőségek kibővítéséről vagy a számlakezelési és ügyintézési folyamatok optimalizálásról, valamint a back-office tevékenységek digitalizációjáról. Ettől némiképp elkülönül a fenntartó újítás, amikor is a fejlesztés kizárólagosan a meglévő folyamatok működőképességének biztosítását célozza, például exogén tényező́k megváltozása esetére. Ezzel szemben a felforgató technológiai újítások alapjaiban képesek megváltoztatni a fennálló üzleti modelleket, több megoldás képes akár a hagyományos pénzügyi szolgáltatók megkerülésével (pl. P2P hitelezés vagy biztosítás), akár automatizált elven történő adatelemzés és -feldolgozás segítségével (pl. robo-advisory) pénzügyi szolgáltatás nyújtására (Bower - Christensen 1995). Szabályozói oldalról elsősorban ez utóbbi innovációk indokolnak fokozott figyelmet, mivel az efféle újításokat alkalmazó piaci szereplők vagy részben, vagy teljes mértékben a szabályozó és a felügyelet hatókörén kívül esnek, miközben jelentős hatással lehetnek a teljes pénzügyi közvetítőrendszerre (MNB 2017).

Technikai korlátja alapvetően nincs annak, hogy a FinTech-innovációk a teljes értékláncot lefedjék a pénzügyi szolgáltatások tekintetében, így jelentős hatással lehetnek az inkumbens intézmények üzleti modelljeire. Az érintett megoldások egy-egy szolgáltatástípus szintjén is megjelenhetnek, de több pénzügyi funkciót is lefedhetnek, sőt akár az inkumbens intézmények teljes helyettesítóivé is válhatnak (MNB 2017). Finanszírozási oldalról a FinTech-cégekbe történő befektetések - kisebb-nagyobb megingásokkal - jelentősen növekedtek az elmúlt években, de globálisan jelentős eltérések láthatók. A kevésbé mély pénzügyi közvetítőrendszerrel rendelkező, gyorsan növekvő ázsiai országokban és Észak-Amerikában kiemelkedő befektetési dinamika tapasztalható, ezzel szemben Európában, hazánkat is beleértve, mérsékeltebb az aktivitás (KPMG 2018).

Az elmúlt években mind a globális, mind a nemzeti szabályozó hatóságok törekvései nagymértékben javították a pénzügyi rendszer sokkellenálló képességét. Az új, sokszor felforgató technológiai innovációkat alkalmazó szereplők megjelenése azonban érdemi hatással lehet nemcsak a pénzügyi stabilitásra, hanem az általános készpénzkeresletre, a pénzügyi rendszer felépítésén keresztül a monetáris politikára, vagy akár a jegybankok végső hitelezési funkciójának keretrendszerére is (Aaron et al. 2017). A szabályozó hatóságok célja ezért egy olyan szabályozási keret kialakítása lehet, amely a pénzügyi stabilitás veszélyeztetése nélkül segíti elő a pénzügyi 
szektorban létrejövő innovációt (MNB 2017). A következőkben ezen innovációk kapcsán felmerülő lehetőségeket és kockázatokat mutatjuk be.

\subsection{A technológiai innovációk lehetséges pozitív hatásai a pénzügyi közvetítésre}

A FinTech-innovációk a pénzügyi közvetítés számos szegmensében javíthatják a rendszer decentralizáltságát és diverzifikáltságát, ami mérsékelheti a jövőbeli pénzügyi sokkok hatásait. Az újítások következtében az új termékek, szolgáltatások, üzleti modellek és piaci szereplők megjelenése olyan alternatív forrásszerzési és befektetési lehetőségeket alakíthat ki, amelyeknek más eszközosztályokkal öszszevetve alacsony a korrelációja. Az új termékek és piaci szereplők megjelenése mérsékelheti a piaci koncentrációt, akár a rendszerszinten jelentős intézmények száma is csökkenhet (FSB 2017).

Az új termékek és szolgáltatások elősegíthetik a pénzügyi integrációt, a pénzügyi közvetítés nagyobb mértékben támogathatja a gazdasági fejlődést. Az innovációknak köszönhetően a pénzügyi szolgáltatások szélesebb fogyasztói és befektető kör számára lehetnek elérhetők (Nicoletti 2017; FSB 2017; EC 2017; Philippon 2016). Ez különösen azon fogyasztói rétegek, régiók esetében lehet fontos, ahol jelenleg korlátozottan áll rendelkezésre pénzügyi szolgáltatói kapcsolat vagy fejlettebb pénzügyi infrastruktúra.

A FinTech-innovációk érdemi hatékonyságnövekedést indukálhatnak a pénzügyi rendszerben (McKinsey 2016; FSB 2017; Nicoletti 2017):

- Back-office funkciók racionalizálása: Az inkumbens intézmények számos olyan új technológiát adaptálhatnak a múködésükbe, amelyek csökkenthetik a back-office tevékenység komplexitását és költségeit. Az automatizált, algoritmussal vezérelt pénzügyi tervezésnek köszönhetően a jogszabályi megfelelés is hatékonyabbá és olcsóbbá válhat (RegTech). ${ }^{2}$

- Döntéshozatali folyamatok optimalizálása: A gépi tanulás és a mesterséges intelligencia adaptálása új alapokra helyezheti az intézmények és a befektetők döntés-előkészítésben alkalmazott modelljeit.

- Fiókhálózat csökkenése: Az intézmények szolgáltatásaihoz való online hozzáférés és az online ügyintézés lehetőséget teremt a legtöbb pénzügyi szolgáltatás online igénybevételére. A csökkenő offline ügyintézésre való igény következtében az egyes szolgáltatók fiókhálózata racionalizálható, amely folyamatot gyorsíthatja az innovatív szereplők piacra lépése.

- Keresési költségek csökkenése: A fejlett Big Data alapú elemzési módszerek és összehasonlító algoritmusok alkalmazásával a keresési költségek csökkenthetők,

\footnotetext{
${ }^{2}$ A RegTech és SupTech fogalmáról lásd részletesen: MNB (2017).
} 
hatékonyabb tőkeallokációs döntések meghozatalára nyílik mód, mind intézményi, mind fogyasztói oldalról.

- Gyorsabb tranzakcióvégrehajtás: A technológiai innovációk érdemben gyorsíthatják a tranzakciók elszámolási idejét, ami csökkentheti a piaci szereplők egymásra utaltságát. A hatékonyabb elszámolás kockázatcsökkentő hatása kevesebb lekötött tőkét és biztosítékot igényel, ezáltal hatékonyabb tőkeallokációs döntések hozhatók.

- RegTech-megoldások megjelenése: A jogszabályi megfelelés érdekében az intézmények innovatív technológiai megoldásokat alkalmazhatnak. A technológiák alkalmazásának szabályozói ösztönzése intézményi oldalon új kockázatok kezelését teszi szükségessé. A jogszabályi megfelelés innovatív eszközei azonban jelentősen képesek növelni a kockázatok azonosításának, és magának a jogszabályi megfelelésnek is a hatékonyságát.

- SupTech-innovációk alkalmazása: A felügyelésben alkalmazandó digitális, automatizált megoldások implementálása a pénzügyi rendszer felügyeletét teheti hatékonyabbá. A SupTech-megoldások célja a vizsgálatok technológiai és IT-szemléletének erősítése, a granuláris adatszolgáltatás létrehozása, illetve automatizált felügyelési mechanizmusok kialakítása lehet többek között.

\subsection{A technológiai innovációk lehetséges kockázatai a pénzügyi közvetítés kapcsán}

\subsubsection{Mikroprudenciális kockázatok}

A FinTech-szereplők gyors növekedése a finanszírozási kockázatok jelentős növekedésével járhat. A piaci részesedés mielőbbi növelése céljából egy szereplőnél - különösen, ha szabályozatlan a tevékenysége - a tőkeáttétel szintje jelentősen megemelkedhet, a rendelkezésre álló likvid eszközeinek aránya pedig csökkenhet. Megnő annak a kockázata, hogy érdemi lejárati eltérés alakuljon ki az eszközök és források között, valamint hitelezési tevékenység esetén jelentős kamatkockázat is felmerülhet. Turbulencia idején vagy ideiglenes működési anomáliák következtében ezek a kockázatok rövid időn belül realizálódhatnak (FSB 2017; BIS 2018). Az inkumbens intézmények számára a piac új szereplői téves ösztönzőket generálhatnak. Az erősödő versenyhelyzet okán a jövedelmezőség fenntartását célozva ezen intézmények kockázati étvágya növekedhet, növelve ezzel a pénzügyi rendszer sérülékenységét (BIS - FSB 2017).

A FinTech-megoldások kapcsán többféle működési kockázat is felmerülhet. Múködési kockázatok természetesen valamennyi vállalkozás életében előfordulhatnak, ezek kiterjedhetnek az információs rendszerek hiányosságaira, az emberi hibákra, valamint külső behatásokra is. A FinTech-innovációk esetében azonban ezek mellett az adatminőségi és adatvédelmi kérdések, valamint a kiberkockázat azok, amelyek további jelentős rizikófaktorral rendelkeznek (BIS 2018; FSB 2017): 
- Adatminőség és adatvédelem: A FinTech-innovációk múködését alapjában jellemzi a nagy mennyiségű megosztott adat és azok széles körü felhasználása, elemzése. Esetleges adatkezelési hiányosságok, problémák vagy az adatminőség-romlás következtében az automatizált folyamatok és elemzések téves eredményekhez vezethetnek, ami miatt fennáll az ügyfelek tévedésének, megtévesztésének, illetve megkárosításának veszélye, de akár illetéktelen adatfelhasználás is felmerülhet.

- Kiberkockázat: A technológiai fejlődés következtében a piaci szereplők müködése komplex IT-rendszereken és szoftvereken alapul. Ezen informatikai rendszerek áttekintése bonyolult és időigényes lehet, esetleges sérülékenységüknek a megállapítása nehézkes, ezáltal belső és külső kockázatoknak egyaránt kitett rendszerek alakulhatnak ki. Bizonyos tevékenységek kiszervezése harmadik feles szolgáltatóknak tovább ronthatja a múködés átláthatóságát, illetve ezen szolgáltatók esetleges múködési zavarai növelhetik a FinTech-megoldások üzleti modelljeinek sérülékenységét.

\subsubsection{Makroprudenciális kockázatok}

Rendszerszintű kockázatot jelenthet, hogy újfajta, rendszerszinten jelentős intézmények, valamint tevékenységek jöhetnek létre ${ }^{3}$. Komoly versenyelőnyhöz juthatnak azok a piaci szereplők, amelyek elsők között adaptálnak egy újszerű megoldást a pénzügyi közvetítésben. Ez a koncentrációs kockázatok növekedésével járhat. Amennyiben egy szűkebb szegmensben meghatározóvá váló szereplőt valamilyen sokk ér, a helyettesíthetősége problémás lehet a várhatóan sajátos üzleti modell miatt. Az egyes szereplők múködését meghatározó és összekapcsoló innovatív technológiák és megoldások terjedése révén nem kizárólag intézmények, hanem akár egyes tevékenységek is rendszerszinten jelentőssé válhatnak (BIS - FSB 2017).

A FinTech-innovációk széles körü felhasználása erősítheti a pénzügyi szektor prociklikusságát is. A pénzügyi rendszer, főként a kereskedelmi banki hitelezés prociklikus jellegű, hiszen gazdasági fellendülés esetén a bankok hajlamosak arra, hogy lazítsák a hitelezési feltételeket, míg gazdasági dekonjunktúra esetén a jövedelmezőség és tőkehelyzet romlását fékezve jelentősen visszafoghatják hitelezési tevékenységüket. A FinTech-innovációk hatására a pénzügyi szektor prociklikus működése erősödhet, egyrészt a piaci szereplők automatizált és hasonló mintázatokat követő döntéshozatala, másrészt a fokozódó piaci verseny révén (FSB 2017). Az FinTech-innovációk fokozott terjedése akár azt is előidézheti, hogy a pénzügyi rendszer az egyes iparági hírekre, változásokra érzékenyebben reagáljon, így rendszerszinten érdemben nőhet a volatilitás.

\footnotetext{
${ }^{3}$ Érdemes megjegyezni, hogy a FinTech-innovátorok megjelenése kapcsán a szakirodalom mind a rendszerszinten jelentős intézmények csökkenését, mind azok növekedését elképzelhetőnek tartja.
} 
A gazdasági szektorok közötti fertőzési csatornák növekedhetnek. Az új üzleti modellekben közvetlen interakció alakulhat ki a kereslet és a kínálat között, ami megnöveli a piaci szereplők közötti csatlakozási pontok számát, a lakosság és a vállalkozások közvetlen finanszírozóként és befektetőként is megjelenhetnek. Mivel az innovációs törekvések fő célja jellemzően az automatizált és mesterséges intelligencia alapú múködés kialakítása, a folyamatok ember általi felügyelete is mérséklődik, ami nem várt kockázatok realizálódását is jelentheti (FSB 2017). Számos piacon az inkumbens intézmények közötti nagyfokú összeköttetés továbbra is fennmaradhat, ami kiegészülhet az informatikai rendszerek összekapcsolódásával. A kapcsolódási pontok növekedése, az informatikai rendszerek és felületek egységesedése, valamint a reálgazdasági szereplők beépülése a közvetítésbe számos kockázati pontot jelenthet a teljes pénzügyi rendszer számára, a transzmissziós csatornákon keresztül pedig több gazdasági ágazatra is átgyürüzhetnek a potenciális kockázatok (Deutsche Bundesbank 2017).

\subsection{3. Ügyfeleket érintő hatások}

Mind fogyasztóvédelmi, mind adatvédelmi oldalról kockázatot jelenthet, hogy az egyes innovatív megoldások alkalmazása során a pénzügyi szolgáltatok egyedi információkat is felhasználnak. A személyes adatok nem megfelelő kezelése vagy akár azok illetéktelen felhasználása megtévesztheti, károsíthatja a fogyasztókat és a befektetőket. A fogyasztóvédelmi kérdések a határon átnyúló, külföldi tranzakciók és szolgáltatások esetén is meghatározók lehetnek a jövőben (BIS - FSB 2017).

\section{1. táblázat}

A FinTech-innovációkban rejlő lehetőségek és kockázatok

\begin{tabular}{l|l|l}
\multicolumn{1}{c|}{ Terület } & \multicolumn{1}{c}{ Lehetőség } & \multicolumn{1}{c}{ Kockázat } \\
\hline Mikroprudenciális & $\begin{array}{l}\text { Piaci múködési } \\
\text { hatékonyság, } \\
\text { alacsonyabb } \\
\text { költségszint }\end{array}$ & $\begin{array}{l}\text { Túlzott kockázatvállalás egyedi szinten (tőkeáttétel, } \\
\text { likviditás, lejárati eltérés), fenntarthatatlan üzleti } \\
\text { modellek megjelenése, növekvő működési } \\
\text { kockázatok (adatminőség, kiberkockázatok) }\end{array}$ \\
\hline Makroprudenciális & $\begin{array}{l}\text { Diverzifikáció, } \\
\text { decentralizáció }\end{array}$ & $\begin{array}{l}\text { Erősödő prociklikusság (akár más szektorokra } \\
\text { átgyúrúző hatással), új, rendszerszinten jelentős } \\
\text { intézmények és szolgáltatások megjelenése, } \\
\text { a szabályozói arbitrázs erősödő lehetősége }\end{array}$ \\
\hline $\begin{array}{l}\text { Ügyfeleket érintő } \\
\text { hatások } \\
\text { (fogyasztóvédelem, } \\
\text { adatvédelem) }\end{array}$ & $\begin{array}{l}\text { Növekvő pénzügyi } \\
\text { integráltság, csökkenő } \\
\text { keresési költségek, új } \\
\text { termékek, } \\
\text { szolgáltatások }\end{array}$ & Ügyfélvédelem kihívásai, adatvédelmi kockázatok \\
\hline
\end{tabular}

Forrás: BIS (2018), FSB (2017) és MNB (2017) alapján szerkesztve 


\section{Potenciális szabályozói válaszok a FinTech-jelenség adta kihívásokra}

\subsection{Szabályozói dilemma a FinTech-megoldások kapcsán}

A FinTech-megoldásokkal kapcsolatosan a szabályozói dilemma alapvetően a „laissez-faire" és a teljesen tiltó szabályozói hozzáállás közötti egyensúly megtalálása (1. ábra). Az optimális keretrendszer megalkotása az egyenlő versenyfeltételek biztosításán alapul. Lényeges továbbá a szereplők ösztönzése, hogy a rendszerkockázatokat is figyelembe vegyék saját múködésük során az egyedi kockázatok mellett (He et al. 2017). A szabályozási keretrendszer kialakítását nehezítheti az új technológiákhoz szükséges szakértelem korlátozott rendelkezésre állása. Ráadásul a FinTech-iparágban megjelent technológiai újításokra jelenleg is nagyfokú heterogenitás jellemző, a jövőben pedig még komplexebb piac kialakulása várható (MNB 2017).

\section{1. ábra}

A FinTech-megoldásokkal kapcsolatos szabályozói dilemma

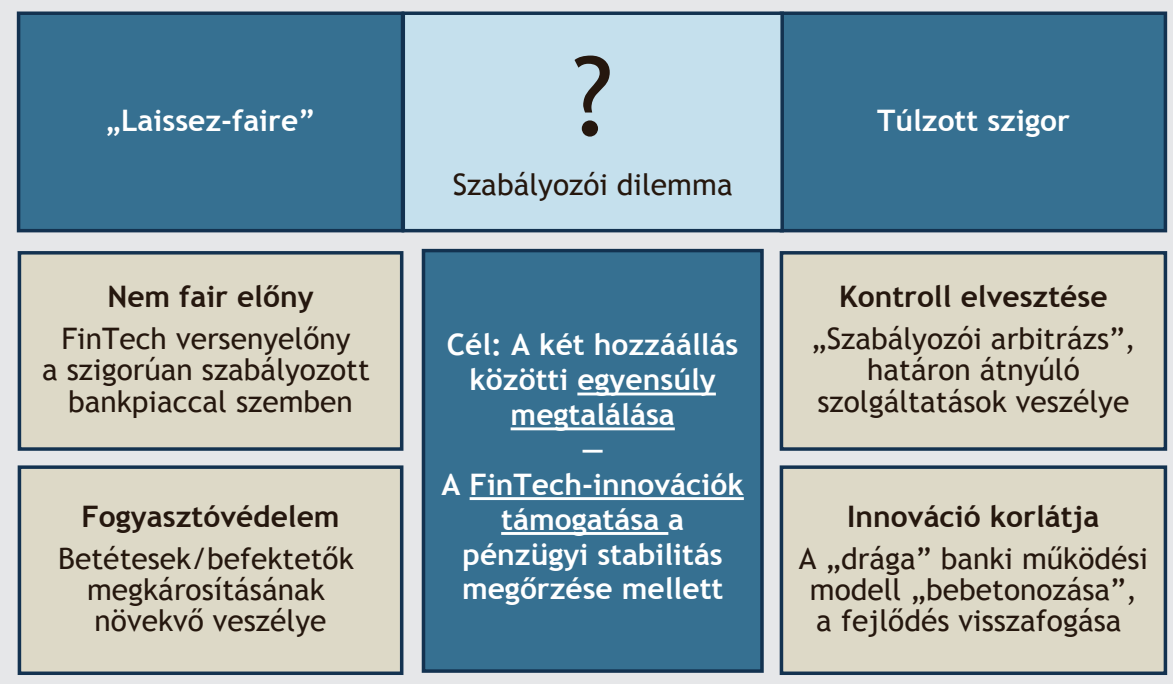

Forrás: MNB (2017)

Egy túlzottan megengedő szabályozói hozzáállás - az erősödő versenyen keresztül - mérsékelheti a szolgáltatások árát, ugyanakkor fogyasztóvédelmi szempontból ez a megközelítés számos kockázatot hordoz magában. A pénzügyi szereplőket érintő szigorú szabályozási követelményekhez képest jogosulatlan versenyelőnyt élveznének a FinTech-intézmények. A szabályok hiánya az érintettek számára is veszélyeket hordoz. Például egy nem kellően érett megoldás mind a fogyasztók, mind a finanszírozók számára nem várt veszteségeket okozhat. További veszélyt 
jelenthet, hogy a pénzügyi közvetítés egy olyan szegmensbe tolódhat át, amelyre a szabályozó hatóságoknak már csak közvetett ráhatásuk lesz. Ennek következtében a kevesebb tapasztalattal rendelkező, új piaci szereplők hatékony kockázatkezelési mechanizmusa sem tud kialakulni (Zetzsche et al. 2017; MNB 2017).

A FinTech-megoldások teljes tiltása ugyanakkor visszafoghatja az innovációkat. Az innováció fékezése mellett egy túlzottan szigorú szabályozási környezetben mind az innovációk, mind az ügyfelek elfordulhatnak a hazai piactól. A határokon átívelő lehetőségek kihasználása valószínűleg még tovább emelné a hagyományos pénzügyi szolgáltatások költségeit, mivel az új, külföldi lehetőségeket preferáló fogyasztók elvándorlását magasabb árakkal ellensúlyoznák a hazai szereplők (WEF 2016). Az új belépők és a verseny hiánya az elmúlt évtizedekben a hazai pénzügyi szektor fő problémája volt, mivel a pénzügyi szolgáltatások továbbra is drágák hazánkban, és az eddigi innovációk sem jártak jelentős előnyökkel a fogyasztók számára (Nagy Vonnák 2014).

A felmerülő pénzügyi innovációkra válaszul a szabályozó legfontosabb feladata egy olyan egyensúly megtalálása lehet, mely amellett, hogy biztosítja a FinTech-megoldásokkal kapcsolatos fogyasztóvédelmi és versenyjogi garanciákat, nem válik az innováció gátjává. Összességében a gazdaság hosszú távú teljesítményét, versenyképességét érdemben befolyásolhatja, hogy miként kezeli egy adott szabályozói rendszer a FinTech-innovációk megjelenését, mennyire tudja megfelelően ösztönözni elterjedésüket a kockázatok hatékony kezelése mellett (MNB 2017). Ezen egyensúly megtalálásához az ún. Innovation Hub és Regulatory Sandbox szabályozói koncepciók alkalmazása nyújthat megoldást ${ }^{4}$.

Az új technológiák az egyes gazdasági szektorokban jellemzően hosszú távon jelentős potenciállal rendelkeznek, azonban azok kifejlődésében és széleskörű elterjedésében különféle szakaszok azonosíthatók. Az ún. „hype”-ciklus áttekintést ad arról, hogy az új technológia, illetve annak alkalmazása miként változik az idő múlásával (Gartner 2017). A ciklusnak 5 fázisa azonosítható: az innováció kialakulása, a növekvő piaci érdeklődés következtében kialakuló, felnagyított piaci várakozások, az átmeneti bizalomvesztésből fakadó illúzióvesztés, a fenntartható fejlődést megalapozó „megvilágosodás” folyamata, valamint az innovatív technológiából eredő, értékteremtő folyamatok tényleges kialakulása, azaz a termelékenység hosszabb távú javulása (lásd 2. ábra).

\footnotetext{
${ }^{4}$ Ezen fogalmakra még nem alakult ki a hazai szakirodalomban széles körben elfogadott fordítás, így jelen tanulmányunkban alapvetően az angol kifejezéseket használjuk. Az MNB - az angol kifejezés mellett a Pénzügyi Innovációs Platform és a Pénzügyi Innovációs Tesztkörnyezet elnevezéseket használja.
} 


\section{2. ábra}

A hype-ciklus az idő és a várakozások függvényében

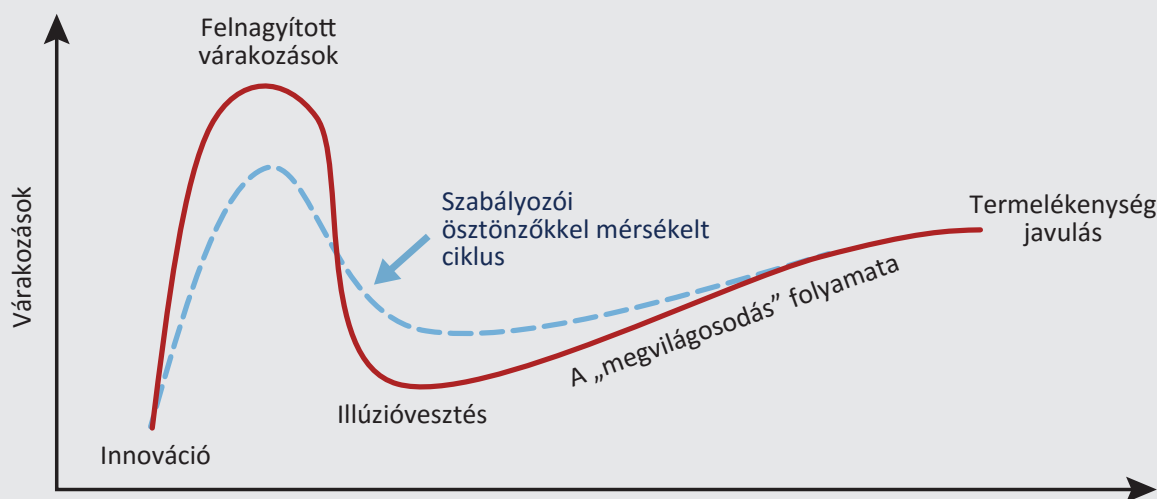

Idő

Forrás: Gartner (2017) alapján szerkesztve

A támogató szabályozói hozzáállás, például egy Innovation Hub vagy egy Regulatory Sandbox alkalmazása kedvezően hathat a felnagyított várakozások okozta kilengések enyhítésére. Egyrészt a megfelelő szabályozói eszközök segítségével az üzleti modellek átgondoltsága javítható, aminek következtében már a fejlődés korai szakaszában olyan termékek vagy szolgáltatások léphetnek be a piacra, amelyek várhatóan meghatározó értéktöbbletet képviselnek. Másrészt ezzel párhuzamosan a piaci kudarcok is mérsékelhetők, így az illúzióvesztés okozta bizalomvesztés hatása is kisebbnek bizonyulhat.

\subsection{Az Innovation Hub mint támogató szabályozói eszköz}

Az Innovation Hub egy, a szabályozó hatóság által biztosított platform, ahol a FinTech-innovátorok iránymutatást kaphatnak a szabályozótól. Keretében a szabályozó hatóság szakértői megválaszolják a FinTech-innovációk képviselőitől érkező kérdéseket, és segítenek értelmezni a jogszabályi előírásokat, valamint felmérik a jogszabály-változtatási igényeket, amelyeket továbbítanak a döntéshozókhoz (az általános szabályozói környezet ezáltal is kedvezőbb lehet az innovációk számára). Az intézmény egyaránt elérhető szabályozatlan, illetve aktuálisan szabályozott tevékenységek számára, továbbá jellemzően mind az újonnan alakult vállalatok újításai, mind az inkumbens intézmények (pl.: bankok, biztosítók) új technológiai megoldásai megjelenhetnek benne.

Az Innovation Hub tevékenységi köre széles spektrumot lefedhet. Alapesetben a főként banki szolgáltatásokat érintő FinTech-specifikus kérdések megválaszolására jöttek létre az Innovation Hubok, de a növekvő piaci igényekre reagálva az iránymutatás-kérés jellemzően a pénzügyi közvetítőrendszer további szegmenseire is kiterjedhet, például az InsurTech- vagy RegTech-területek bevonásával. A direkt 
megkeresésekre adott iránymutatásokon kívül több hub is lehetőséget biztosít a folyamatos kapcsolattartásra, amelynek keretében a hatóságok a tevékenységi engedélyek megszerzését is segítik. Az újonnan létrejött vállalatokat a hub üzemeltetői meghatározott ideig, jellemzően az engedélyszerzést követően további 12 hónapig figyelemmel kísérik és támogatják.

Az Innovation Hub előnye, hogy az innovátorok egy dedikált csatornán tehetik fel konkrét kérdéseiket, ami segíti a válaszadási folyamat gyorsaságát. További sajátossága, hogy a kérdés előzetes szúréshez kötött. Ezen kritérium célja, hogy az innovátorok már a kérdésfeltevés előtt megfelelő mértékben tájékozódjanak lehetőségeikről és várható kötelezettségeikről. Az innovátoroknak rendszerint néhány kérdés alapján meg kell vizsgálniuk ötletük piaci elérhetőségét, valamint annak újdonságtartalmát és várható hatásait a potenciális érintettekre és az adott ország gazdaságára (MNB 2017).

\subsection{A Regulatory Sandbox koncepciója}

A Regulatory Sandbox segítségével az innovátorok egy, a szabályozó által kontrollált „tesztkörnyezetben” vizsgálhatják meg pénzügyi termékük, üzleti modelljük életképességét bizonyos szabályozói kötelezettségek alóli időszakos mentességet élvezve. A tesztek valós fogyasztók bevonásával történnek. A Sandboxok közös jellemzője, hogy csupán meghatározott időre - jellemzően 6-12 hónapra -, és csupán az előre meghatározott számú ügyfél tekintetében engedélyezik az innováció valós piaci körülmények közötti tesztelését. Ez idő alatt a szabályozó eltekint egyes, előre meghatározott szabályozói elvárások teljesítésétől. A tesztbe való bejutás lényegi feltétele jellemzően, hogy az innováció a fogyasztók vagy az ügyfelek számára jelentős újdonságtartalommal bírjon, illetve hogy az azt alkalmazó általában véve megfeleljen a piacra lépés követelményeinek. Amennyiben a tesztelés során bebizonyosodik a szolgáltatás életképessége, azt követően megtörténhet a tényleges piacra lépés.

Annak függvényében, hogy a koncepció melyik ország jogrendszerében valósult meg, és az a jogrendszer milyen feltételek mentén engedi a koncepció múködését, minden Sandbox rendelkezik egy, a jogi alkalmazást biztosító eszközkészlettel. A felügyelő hatóság bizonyos esetekben olyan, a felügyeleti intézkedések korlátozására vonatkozó szándéknyilatkozatokat („no enforcement action letters” - NAL) tehet, amelyek a tesztelési feltételek betartásáig maradnak érvényben, és amelyek a jogszabályi környezetnek való megfelelés érdekében egyedi iránymutatást is adhatnak a tesztelőnek. A felügyeleti engedéllyel nem rendelkező cégek számára korlátozott, ideiglenes múködési engedély is biztosítható. A múködési engedély iránti kérelem ilyen esetekben gyorsabb elbírálás alá kerülhet, és a szabályozói kötelezettségek is mérsékeltebbek lehetnek ezekben a kezdeti fázisokban (MNB 2017). 


\section{Nemzetközi kezdeményezések}

Egyre több ország ismeri fel, hogy a FinTech-jelenség megfelelő szabályozói választ kíván. Az innovációt támogató nemzeti felügyeleti gyakorlat ugyanakkor nem konzisztens. Kevés országban hoztak eddig létre a FinTech-újítások terjedését ösztönző dedikált kereteket. A legjellemzőbb, hogy a felügyelet egyedi lépéseket tesz. Ezek keretében a piaci szereplők számára rendszerint lehetőség nyílik arra, hogy az adott országban érvényes jogszabályi keretrendszert - különösen a fejlesztés alatt termékükhöz vagy szolgáltatásukhoz szorosan kapcsolódó kötelezettségeket - részletesebben megismerjék, valamint konzultációk keretében támogatást kapjanak a tevékenységi engedély megszerzésének folyamata során. Innovation Hub-ok felállítására jelenleg még csak kevés országban került sor, világszerte kevesebb, mint húsz ilyen dedikált keretrendszer üzemel ${ }^{5}$ (BIS 2018). Az európai előfordulást foglalja össze a 3. ábra.

\section{3. ábra \\ Innovation Hubok és egyéb innovációt támogató felügyeleti megoldások Európában}

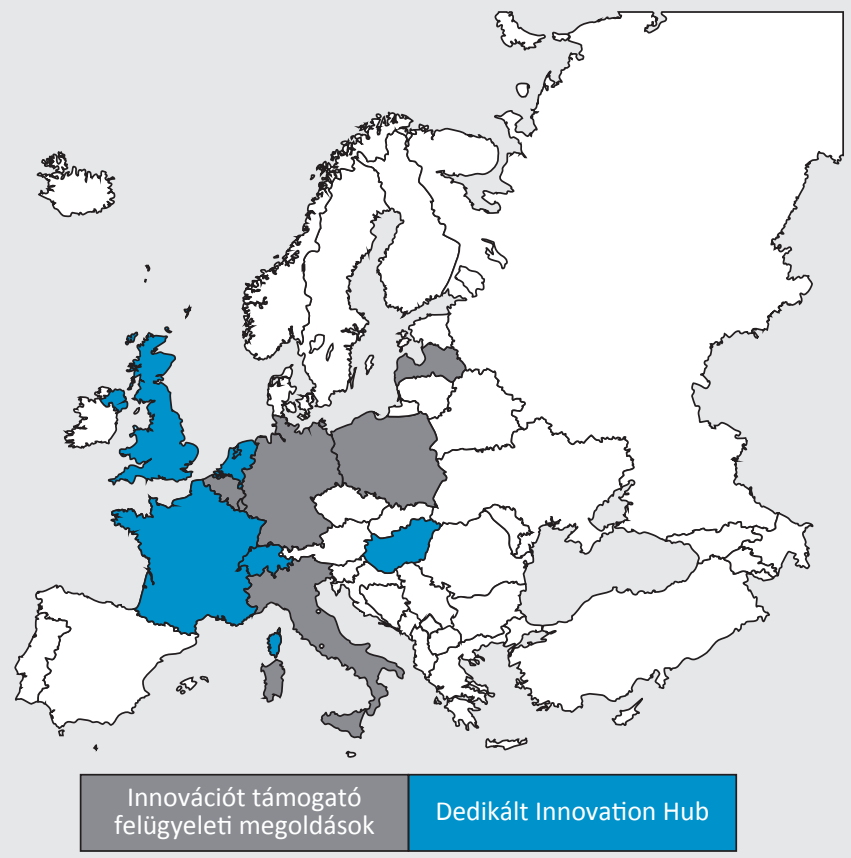

Forrás: BIS (2018), saját gyüjtés

\footnotetext{
${ }^{5}$ Megjegyezzük, hogy létezik még több intézmény is világszerte, amit Innovation Hub-nak neveznek, de a tanulmány csak azokat teszi ezen kategória alá, amelyek funkciójukat és eddigi tevékenységüket alaposabban vizsgálva átfogó szolgáltatásokat nyújtanak a FinTech-innovátorok számára.
} 
A Regulatory Sandbox keretrendszer elterjedése sem széleskörű még jelenleg (lásd 4. ábra). Az Egyesült Királyságban történt első alkalmazás óta a már ténylegesen müködő Sandboxok száma nem éri el a tízet, alkalmazása leginkább Ázsiában jellemző. A prominens brit példán kívül Európában jelenleg Hollandia és Svájc üzemeltet csak dedikált Regulatory Sandboxot. Hollandiában a nyilvánosan elérhető információk alapján tesztelésre még nem került sor, Svájc esetében a Sandbox elsősorban egy korlátozott hatókörű tesztkörnyezetként funkcionál: az 1 millió svájci frankot nem meghaladó betétgyújtési tevékenység banki licenc nélküli végzését teszi lehetővé. Litvánia 2017 nyarán indított hivatalos konzultációt a Sandbox bevezetéséról.

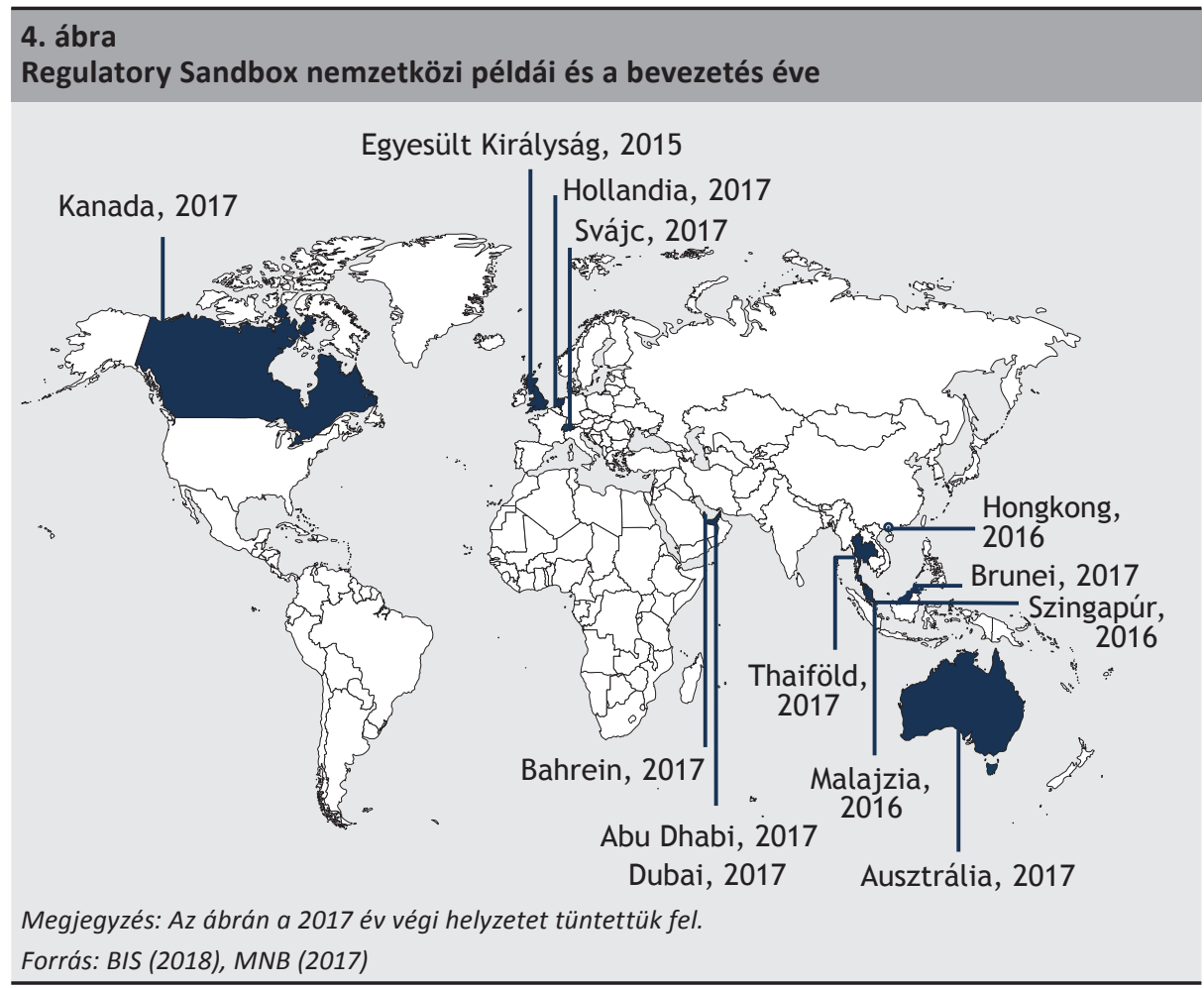

Uniós szinten több kezdeményezés van kibontakozóban a FinTech-jelenségre adható koordinált válaszok kidolgozására. 2016-ban az Európai Bizottság munkacsoportot állított fel a vonatkozó szabályozás kialakítására. Feladata a fennálló szabályok felülvizsgálata abból a szempontból, hogy azok megfeleljenek a digitális kor kihívásainak. A munkára alapozva 2018-ban publikálták az EU FinTech-akciótervét (EC 2018). Az Európai Bankhatóság szintén kidolgozta ütemtervét a 2018/2019-re vonatkozó időszakra, ahol figyelembe vették az általuk 2017-ben lefolytatott piaci konzultáció eredményeit is (EBA 2017, 2018). Az Európai Központi Bank (EKB) egyrészt nyilvános konzultációt indított az új típusú, FinTech üzleti modellt alkalmazó bankok múködésének feltételeivel kapcsolatosan, miután a FinTech-megoldások 
terjedésével növekvő számú múködési engedély iránti kérelem érkezik hozzájuk (EKB 2017a). Másrészt az EKB 2017 márciusában közleményt adott ki, amelyben célkitűzésként szerepel egy eurozónát lefedő FinTech Hub kialakítása. A 19 ország számára egységesen elérhető jövőbeli platform célja az információcsere facilitálása, valamint a nemzetközi jó-gyakorlatok megosztása lenne (EKB 2017b).

\section{Az optimális szabályozói válasz nyomában: az egyes Regulatory Sandboxok jellegzetességei}

Tekintettel arra, hogy a Regulatory Sandbox keretrendszerek egy különleges jogi konstrukciót testesítenek meg, érdemes megvizsgálni, milyen jogtechnikai megoldásokat alkalmaznak az egyes országok a tesztkörnyezet múködtetéséhez. A továbbiakban ennek érdekében áttekintjük a legismertebb Regulatory Sandboxok esetében alkalmazott gyakorlatokat, kitérve az ázsiai, az angolszász és a kontinentális európai jogrendszerekben látható megoldásokra is. Mivel a korábbiakban már bemutatásra kerültek a Sandbox-jellegű keretrendszerek generális attribútumai, jelen fejezetben elsősorban az egyes nemzeti jogalkotók által megvalósított megoldások specialitásait vesszük górcső alá.

\subsection{Regulatory Sandboxok nemzetközi gyakorlata}

Bár az egyes keretrendszerek ugyanazon célt szolgálják, a konkrét megvalósítás tekintetében számos sajátosság azonosítható az egyes országok esetében ${ }^{6}$ :

- Szingapúr: A Monetary Authority of Singapore (MAS) által 2016-ban kidolgozott keretrendszer sajátossága, hogy a tesztelési időszak meghosszabbítható abban az esetben, ha a tesztelő bizonyítja, hogy további időre van szüksége a teljes jogszabályi környezetnek való megfelelés érdekében, illetve ha a tesztelés során a fogyasztói visszajelzések miatt időközben megváltoztatta az eredetileg tesztelt szolgáltatását (MAS 2016). Az időbeli hosszabbítás mellett a keretrendszer a tesztelési paraméterek kibővítésére is lehetőséget nyújt. Az előreláthatóan sikertelen tesztelés esetén azonban a tesztelési időszaknak vége szakad. ${ }^{7}$

- Malajzia: A maláj rendszerben egy teljesen rugalmas megközelítés képe bontakozik ki. Ez megállapítható többek között abból a tényből, hogy még az olyan alapattribútumokat is, mint a fogyasztók korlátozott száma vagy a tesztelési lehetőség időbelisége, rugalmasan kezeli, és azok alól - legalábbis elméletben, a szabályrendszer szintjén - kivételt enged (BNM 2016).

\footnotetext{
${ }^{6}$ A korábban jelzetteknek megfelelően Svájcban, Kanadában és több más, jellemzően ázsiai országban szintén müködik Regulatory Sandbox, azonban ezen országok kapcsán a jogrendszer sajátosságai, illetve az elérhető információk szűkössége miatt nem végezhető jelenleg megfelelő összehasonlítás.

${ }^{7}$ A tesztelési időszak lezárásáról szóló döntés eseteit tételesen felsorolja a szingapúri hatóság tájékoztatója, ezek:

a) a MAS diszkréciójába tartozó döntés értelmében nem elégséges a tesztelés által elért eredmény;

b) a vállalkozás nem lesz képes teljesíteni a vonatkozó jogi előírásokat a tesztelési időszak végére;

c) nyilvánvalóvá válik, hogy a tevékenységhez kapcsolódó fogyasztói kockázatok nagyobbak, mint az elérhető előnyök;

d) a vállalkozás megszegi az elöre meghatározott tesztelési feltételeket;

e) a vállalkozás saját döntése értelmében.
} 
- Ausztrália: Az ausztrál értékpapír-felügyelet (ASIC - Australian Securities \& Investments Commission) által 2016 decembere óta múködtetett keretrendszer sajátossága, hogy nem csupán egyedi jogi személyek jelentkezése alapján nyújt egyedi felmentéseket, de - amennyiben annak az ausztrál jog szerinti feltételei fennállnak - előre meghatározott tevékenységi osztályba tartozó tevékenységek folytatása tekintetében is mentességet biztosíthat, függetlenül a tevékenység végzőjének személyétől. A rendszer további különlegessége, hogy bizonyos speciális körülmények fennállta esetén a múltbéli nem megfelelés jövőbeli következményei vonatkozásában a hatóság megteremti a lehetőségét a visszaható hatályú mentesítésnek is.

- Egyesült Királyság: A brit pénzügyi felügyelet szerepét betöltő Financial Conduct Authority (FCA) a Sandboxban potenciálisan alkalmazható eszközök széles tárházát teszi elérhetővé, úgymint a jogérvényesítést kizáró, dedikált felügyelői nyilatkozat, a korlátozott engedély megszerzése iránti eljárás, illetve a mentesítési eljárás (FCA 2015a). A felsoroltak közül a korlátozott engedély megszerzése iránti eljárást érdemes kiemelni. Az engedély eredményeképpen egy rugalmas, dinamikusan változó szabályozói keretmechanizmus jön létre a tesztelő vállalkozás számára: a tesztelés minden szakaszában csak azon elvárásoknak kell megfelelnie a tesztelőnek, amelyek az adott időpillanatban arányban állnak a tesztelt tevékenységgel, az FCA folyamatos értékelése szerint. Az egyes, hasonló tevékenységet végző tesztelők közötti egyenlő feltételrendszer kialakítását csoportos tesztelési időszakokkal biztosítják. Ennek megfelelően a tesztkörnyezetbe való jelentkezési időszak a többi Sandboxszal ellentétben nem folyamatos, hanem meghatározott időintervallumokban lehetséges. Említést érdemel továbbá, hogy csak azon vállalkozások léphetnek a Sandboxba, melyek esetében az FCA egyedileg ellenőrizte, hogy a tesztelt szolgáltatás kapcsán a fogyasztók megfelelő tájékoztatásban részesültek, illetve hogy megfelelő védelmet, ezen belül kielégítő mértékű kártalanításra való jogosultságot kapnak.

- Hollandia: A holland koncepció - többek között a jelentős részben nemzeti hatáskörben nem változtatható uniós szabályozások kiterjedtsége miatt - nem vonatkozik a kötelező hatályú jogi előírások szférájára. Ezzel összhangban a holland keretrendszer az innovatív megoldás technológiai jellemzőire koncentrál, illetve arra, hogy azok pozitív hatása érezhető legyen a pénzügyi rendszer stabilitása, hatékonysága és a fogyasztók biztonsága tekintetében (DNB 2016). Így tehát leginkább egy szolgáltatás jellegű facilitáló keretnek tekinthető, melyben a "soft" szabályozói elvárások játsszák a főszerepet.

\subsection{A Regulatory Sandboxok jogi attribútumai}

A Regulatory Sandboxok nem csak funkcionalitásukban, de a jogi megvalósítás tekintetében is különbözőségeket mutatnak. Az eltéréseket három területen érdemes elemezni. Az első annak áttekintése, hogy a jogintézmény bevezetése milyen jog- 
szabályi változtatásokat jelent, illetve egyáltalán jogszabályi alapokon nyugszik-e, vagy csupán az azok érvényesítésére vonatkozó eszközrendszer alkalmazásának felfüggesztésére terjed ki. A második vizsgálandó ismérv a tárgyi hatály, vagyis hogy milyen kötelezettségek alól lehet mentesülést szerezni a Sandbox kereteiben. Végül vizsgálandó a megvalósult koncepciók személyi hatályának kérdése is (2. táblázat).

\subsubsection{A koncepció kialakitásának jogalkotási terhe és tárgyi hatálya}

A jogalkotási teher és az ehhez szorosan kapcsolódó tárgyi hatály vonatkozásában igen nagy eltérések tapasztalhatók a vizsgált koncepciók tekintetében. A távol-keleti Sandboxokat vizsgálva - a vonatkozó szűk körú információ alapján - arra juthatunk, hogy a tesztelésre vonatkozó mentesítés jogalapja a felügyelet jogalkotási hatáskörébe tartozó aktus. Erre enged következtetni, hogy a Sandboxok keretében csak bizonyos, a felügyelet által elöírt jogi és szabályozói követelmények alól adható felmentés. Ilyen követelmények lehetnek per definitionem a hatóság által kiadott jogszabályok mellett az általuk egyébként elvárt, jogi kötőerővel nem rendelkező aktusok (soft law), illetve a hatóság részére jogszabályok által garantált diszkrecionális mozgástér által lehetővé tett követelményektől való eltekintés.

Az ausztrál koncepció egyértelműen túlmegy a fent bemutatottakon, mivel az ASICnek törvényben meghatározott diszkrecionális jogköre van egy tételesen meghatározott jogszabályi kör ${ }^{8}$ elvárásai alóli mentesítés megadására. Az explicit mentesítési rendszer mellett az ausztrál modell még egy ponton rendelkezik egy jelentős hatékonyságnövelő eszközzel. Abban az esetben ugyanis, ha a felsorolt jogszabályok egyegy rendelkezése homályos vagy nem értelmezhető egyértelműen egy innovációra vonatkoztatva, az ASIC saját döntése nyomán mentesítést adhat azok teljesítése alól is, a Sandbox-koncepció eljárási és egyéb szabályait betartva ${ }^{9}$ (ASIC 2009).

Az FCA az ausztrálhoz hasonló jogrend ellenére alapvetően eltérő jogtechnikai megoldással élt a koncepció kialakítása során. A brit pénzügyi szolgáltatások nyújtásának alapvető szabályait lefektető törvény kimondja, hogy az FCA annyiban adhat tevékenységi engedélyt bármely intézménynek, amennyiben az megfelel az ehhez szükséges feltételeknek, kivéve, ha az FCA mentesíti az intézményt az ezen előírásoknak való megfelelés alól (FCA 2015b). Az FCA tehát már az engedélyezési eljárás során rendelkezhet arról, hogy bizonyos, innovatív megoldást alkalmazó igénylőknek bizonyos engedélyezési kritériumokat nem, vagy csak jóval enyhébb feltételek mellett kell teljesíteniük.

A holland rendszer nem eredményezett jogalkotási terhet, azonban ebből fakadóan hatékonysága viszonylag szúk körben érvényesülhet. A hatóság csupán a „soft law”-

\footnotetext{
${ }^{8}$ Corporations Act 2001 (Corporations Act); Superannuation Industry (Supervision) Act 1933 (SIS Act); National Consumer Credit Protection Act 2009 (National Credit Act); National Consumer Credit Protection (Transitional and Consequential Provisions) Act 2009 (Transitional Act).

9 ún. comfort relief
} 
ra és saját, jogszabályban meghatározott diszkréciójára terjesztheti ki a Sandbox tárgyi hatályát. A mentesítési jogkör csökkenő mértékben ugyan, de vonatkozhat még az európai felügyeleti intézmények (pl. EBA, ESMA) nem kötelező érvényű szabályozói aktusaira is (DNB 2017).

\subsubsection{A koncepció személyi hatálya}

Személyi hatály kérdése alatt az értendő, hogy milyen jogi személyeknek van potenciális lehetőségük Sandbox keretében tesztelni szolgáltatásukat az adott országban. A vizsgált Sandbox-koncepciók sok esetben széles körben megengedik a tevékenységi engedéllyel nem rendelkező vállalkozások potenciális felvételét a tesztelők közé.

A vizsgált távol-keleti megoldások rugalmasan kezelik a jelentkezők körét. A MAS által kialakított koncepció értelmében amellett, hogy természetesen jelentkezhetnek pénzügyi szolgáltatás nyújtására jogosult intézmények, velük versenyre kelhetnek azon vállalkozások is, amelyek az adott pillanatban nem rendelkeznek tevékenységi engedéllyel, de valószínűsítik annak megszerzését. Malajzia szintén hasonló megoldást választott. A Sandboxba való belépés lehetőségét a maláj nemzeti bank (Bank Negara Malaysia - BNM) egyrészt az általa kiadott tevékenységi engedéllyel rendelkező pénzügyi szervezetek számára teszi lehetővé. Ezt a szabályt annyiban lehet tágan értelmezni, miszerint a pénzügyi szervezettel közösen kérheti felvételét az innovációt szállító egyéb vállalkozás is. Másrészt lehetőség van arra is, hogy olyan vállalkozás pályázzon a részvételre, amelyik csak tervezi a pénzügyi szervezetként való működésre vonatkozó engedély megszerzését (BNM 2016).

Az angolszász jogrendszerekben működő koncepciók szintén a fenti hozzáállást erősítik, bizonyos esetekben azonban az engedéllyel nem rendelkező vállalkozások taxatív feltételekkel való előszűrése mellett. Az ASIC több feltétel konjunktív teljesítéséhez köti az engedély nélküli intézmények jelentkezését (ASIC 2017). Ezen feltételek azonban nem csupán az engedélyhez nem kötött tevékenységet végző vállalkozás ilyetén minőségéhez kötődnek, hanem átfogják a belépési kritériumok (eligibility criteria) teljes körét. Az Egyesült Királyság három különböző kategóriát is felállít, a bennük szereplők számára lehetővé téve a jelentkezést. Egyrészt az FCA Sandboxa természetszerúleg nyitva áll tevékenységi engedéllyel rendelkező intézmények számára, másrészt azok számára, amelyek elindították a tevékenység megszerzése iránti eljárást. Harmadrészt, az FCA tevékenységi engedélytől függetlenül lehetővé teszi minden olyan vállalkozás esetén a belépést, mely tevékenysége valamiféle technológiai innovációhoz köthető.

Az uniós jogszabályok jelenleg nem engedik meg az engedély nélküli pénzügyitevékenység-végzést, kivételre tekintet nélkül. Hollandia ennek megfelelően a személyi hatály tekintetében is a legkonzervatívabb álláspontot képviseli, mely szerint kizárólagosan pénzügyi szervezetek számára teszi lehetővé a Sandboxba való jelentkezést (DNB 2016). A bankuniós tagállamokban letelepedni szándékozó pénzügyi 
szervezetek tevékenységi engedélyére vonatkozó eljárást - az egységes felügyeleti mechanizmusra vonatkozó szabályok értelmében - az Európai Központi Bank (EKB) folytatja le, tekintet nélkül az intézmény méretére. Az eljárás során az EKB a releváns közvetlenül alkalmazandó uniós jog mellett köteles alkalmazni az uniós irányelveket átültető tagállami szabályokat is. Mivel ezek minimum harmonizációs előírások, így a tagállami joganyag szigorúbb követelményeket is megállapíthat. Ez utóbbi esetben az EKB - uniós intézményi minőségének ellenére - az engedélyezési követelményekre megállapított, tisztán tagállami szabályok alkalmazására is köteles. Mivel azonban az uniós szabályok nem tartalmaznak pénzügyi innovációk alkalmazása során érvényesíthető mentességi lehetőségeket, így a tagállami szabályok sem határozhatnak meg ilyesmit. Olyan mentesség azonban a jelenleg hatályos uniós szabályok betartása mellett is elképzelhető, mely kizárólag az uniós előírásoknál szigorúbban meghatározott tagállami szabályokkal szemben enged eltérést, egy Sandbox jellegű jogi entitás keretében.

\begin{tabular}{|c|c|c|c|c|}
\hline \multicolumn{5}{|l|}{ 2. táblázat } \\
\hline Térség & Ország & $\begin{array}{c}\text { Jogalkotási } \\
\text { teher/technika }\end{array}$ & Tárgyi hatály & Személyi hatály \\
\hline \multirow[t]{2}{*}{ Távol-Kelet } & Szingapúr & $\begin{array}{l}\text { - Valószínűsíthetően } \\
\text { egy, a MAS jogalkotási } \\
\text { hatáskörébe tartozó } \\
\text { aktus }\end{array}$ & $\begin{array}{l}\text { - A MAS által előírt jogi } \\
\text { és szabályozói } \\
\text { követelmények }\end{array}$ & $\begin{array}{l}\text { - Pénzügyi intézmények } \\
\text { - Engedély megszerzését } \\
\text { valószínúsítő } \\
\text { intézmények }\end{array}$ \\
\hline & Malajzia & $\begin{array}{l}\text { - Valószínúsíthetően } \\
\text { egy, a BNM jogalkotási } \\
\text { hatáskörébe tartozó } \\
\text { aktus }\end{array}$ & $\begin{array}{l}\text { - A BNM által előírt jogi } \\
\text { és szabályozói } \\
\text { követelmények }\end{array}$ & $\begin{array}{l}\text { - Pénzügyi intézmények } \\
\text { - Engedéllyel rendelkező } \\
\text { intézmények és } \\
\text { FinTech-vállalkozások } \\
\text { együtt }\end{array}$ \\
\hline \multirow[t]{2}{*}{$\begin{array}{l}\text { Angolszász } \\
\text { országok }\end{array}$} & Ausztrália & $\begin{array}{l}\text { - Gazdasági törvény } \\
\text { - Felügyeleti törvény } \\
\text { - Fogyasztói hitelről } \\
\text { szóló törvény }\end{array}$ & $\begin{array}{l}\text { - A } 3 \text { törvényben } \\
\text { megjelölt } \\
\text { jogszabályhelyek } \\
\text { • Nem egyértelmúen } \\
\text { értelmezhető } \\
\text { szabályok esetében } \\
\text { „comfort relief” }\end{array}$ & $\begin{array}{l}\text { - Pénzügyi intézmények } \\
\text { - Az ASIC által } \\
\text { meghatározott } \\
\text { feltételeket teljesítő, } \\
\text { engedéllyel nem } \\
\text { rendelkező } \\
\text { intézmények }\end{array}$ \\
\hline & $\begin{array}{l}\text { Egyesült } \\
\text { Királyság }\end{array}$ & $\begin{array}{l}\text { - Pénzügyi } \\
\text { szolgáltatásokról és } \\
\text { piacokról szóló törvény } \\
\text { (FSMA) }\end{array}$ & - Az FCA diszkréciója & $\begin{array}{l}\text { - Pénzügyi intézmények } \\
\text { - Engedélyt hivatalosan } \\
\text { igénylő intézmények } \\
\text { - Engedéllyel nem } \\
\text { rendelkező innovatív } \\
\text { intézmények }\end{array}$ \\
\hline Eurozóna & Hollandia & $\begin{array}{l}\text { - Nem merült fel } \\
\text { jogalkotási teher }\end{array}$ & $\begin{array}{l}\text { - Nemzeti szintű és } \\
\text { Uniós „soft law” } \\
\text { - Jogszabályban } \\
\text { meghatározott } \\
\text { esetleges hatósági } \\
\text { diszkréciók }\end{array}$ & • Pénzügyi intézmények \\
\hline
\end{tabular}




\section{A FinTech-innovációkra vonatkozó hazai kezdeményezések}

A FinTech-iparágra vonatkozó megfelelő szabályozói keretek felállítása nemzetgazdasági szempontból és a pénzügyi rendszer versenyképessége szempontjából is kiemelkedő fontosságú. A FinTech-innovációk felhasználása által hosszabb távon pénzügyi szektorbeli költséghatékonyság-növekedés érhető el, a testreszabott szabályozói válaszok pedig hozzájárulnak a stabilitás erősödéséhez, valamint a fogyasztói többlet potenciális növekedéséhez. Közvetve a magyar gazdaság hosszú távú teljesítményét és versenyképességét is érdemben befolyásolhatja, hogy miként kezeli hazánk a FinTech-innovációk megjelenését. A közép-kelet-európai térség FinTech befektetési aktivitása nemzetközi viszonylatban egyelőre alacsony, amit egy támogató szabályozói keretrendszer kialakítása érdemben javíthat.

A hazai pénzügyi közvetítőrendszerben jelentős igény mutatkozik mind keresleti, mind kínálati oldalon az innovatív pénzügyi szolgáltatások biztonságos alkalmazására. A fogyasztói oldalt tekintve Magyarországon már ma létezik egy olyan jelentős - az MNB Lakossági felmérése alapján mintegy 15-20 százalékos - lakossági réteg, amely érdeklődik a FinTech nyújtotta innovációk iránt. Az aktív népességszámra vetítve ez azt jelenti, hogy mintegy 1 millió fogyasztó már jelenleg is potenciális keresletet támaszthat az új megoldásokra. Az elutasítás mértéke a fiatalabb generációk esetében alacsonyabb, így a jövőben a teljes lakossági nyitottság tovább nőhet (MNB 2017). A hazai iparági szereplők - inkumbens intézmények és újonnan alakult FinTech-cégek - részéről szintén érdemi érdeklődés jellemző a FinTech-innovációk alkalmazására vonatkozólag. Számos intézmény rendelkezik erre vonatkozó tervekkel, illetve sokak esetében már használatban is vannak innovatív megoldások, elsősorban a mobil- és digitális fizetési megoldásokhoz, fizetéskezdeményezési szolgáltatásokhoz kapcsolódóan (MNB 2017).

A nemzetközi gyakorlat feltérképezését és a hazai érintettek álláspontjának felmérését követően 2018 márciusában megkezdte működését a magyar pénzügyi innovációkat támogató MNB Innovation Hub (Pénzügyi Innovációs Platform). ${ }^{10} \mathrm{Az}$ MNB részéről a FinTech-innovációk biztonságos keretek közt történő ösztönzésére irányuló első lépés egy Innovation Hub platform felállítása volt. Az MNB Innovation Hub négy funkciójával segíti az innovatív ötletek megvalósíthatóságát. Az Információs tárház keretében az innovációk kezdeményezői a rájuk vonatkozó jogszabályi elvárások és kötelezettségek kapcsán megfelelő mennyiségú és minőségű, rendszerezett információhoz juthatnak. A Szabályozói támogatói platform lehetőséget kínál az újításokkal kapcsolatban felmerülő jogi kérdések MNB iránymutatás útján való tisztázására. A Kommunikációs hub információmegosztó felületet biztosít a teljes FinTech-ökoszisztéma számára. Az Innovation Hub továbbá egy Nemzetközi koope-

\footnotetext{
${ }^{10}$ https://www.mnb.hu/innovation-hub
} 
rációs platformként is üzemel. Ezen funkció a FinTech-innovációk támogatásában élen járó külföldi szabályozó hatóságokkal való kapcsolat kiépítését szolgálja.

Nemzetközi tapasztalatok alapján a pénzügyi innovációs szféra facilitálásának egy Regulatory Sandbox-típusú keretrendszer létrehozása is fontos eleme. Az MNB a releváns hazai intézményekkel, valamint egyéb érintettekkel egyeztetve már vizsgálja egy Regulatory Sandbox felállításának lehetőségét. A piaci szereplők a visszajelzéseik alapján jelentős számban vennének részt egy erre a célra felállított tesztkörnyezetben (5. ábra), számos potenciális jelentkező pedig már azonosította is, hogy milyen szolgáltatást tesztelne itt ${ }^{11}$.

\section{5. ábra \\ A piaci szereplők (bankok, biztosítók, pénztárak, közvetítők és FinTech-cégek) álláspontja a hazai Regulatory Sandbox felállításáról}
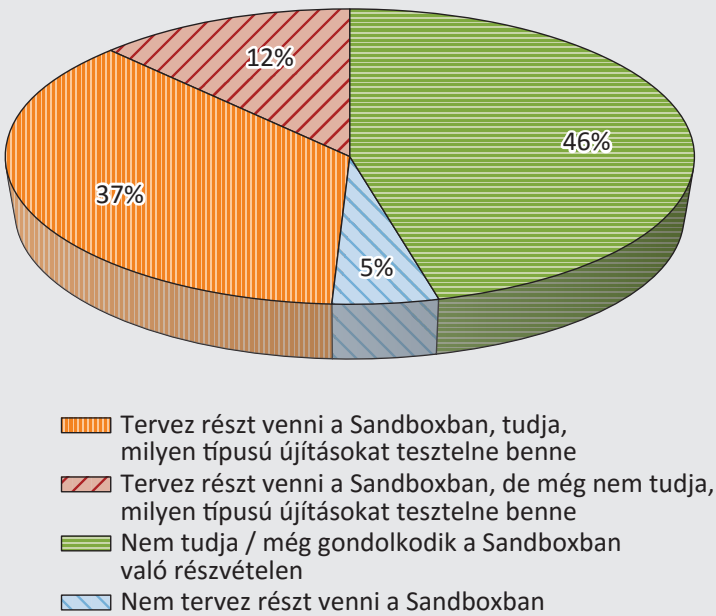

Megjegyzés: 83 piaci szereplő válasza alapján.

Forrás: $M N B$

A FinTech-innovációk hosszabb távon láthatóan a jogszabályi hierarchia minden szintjén változásokat indukálhatnak (6. ábra), hiszen olyan új megoldások vannak születőben, amelyek jogi háttere sok esetben jelenleg egyáltalán nem rendezett. Egyéb esetekben gyakran nem világos, vagy az új megoldásokra vonatkozóan nem egyszerűen értelmezhető jogi keretek vagy jogalkalmazói elvárások jelentenek nehézséget. Az Innovation Hub és a Regulatory Sandbox keretrendszer a piaci szereplők visszajelzései alapján a legtöbb jelenleg felmerülő jogi probléma tekintetében megoldást nyújthat az innovatív megoldások jogi kereteinek tisztázásához. Felmerülhetnek azonban olyan kérdések is, amelyeket csak nemzeti vagy akár EU-s szintű

${ }^{11}$ A felmérés módszertanáról, valamint további eredményeiről lásd az MNB vonatkozó Konzultációs dokumentumát (MNB 2017). 
jogalkotás útján lehet teljes egészében rendezni. Az MNB által létrehozott és bevezetni tervezett szabályozói megoldások ezt a jogalkotási folyamatot is támogathatják a naprakész piaci információk begyűjtése és elérhetővé tétele, valamint az érintett szereplőkkel való folytonos kommunikáció útján.

\section{6. ábra \\ A FinTech-innovációkra vonatkozó szabályozói környezet szintjei hazánkban}

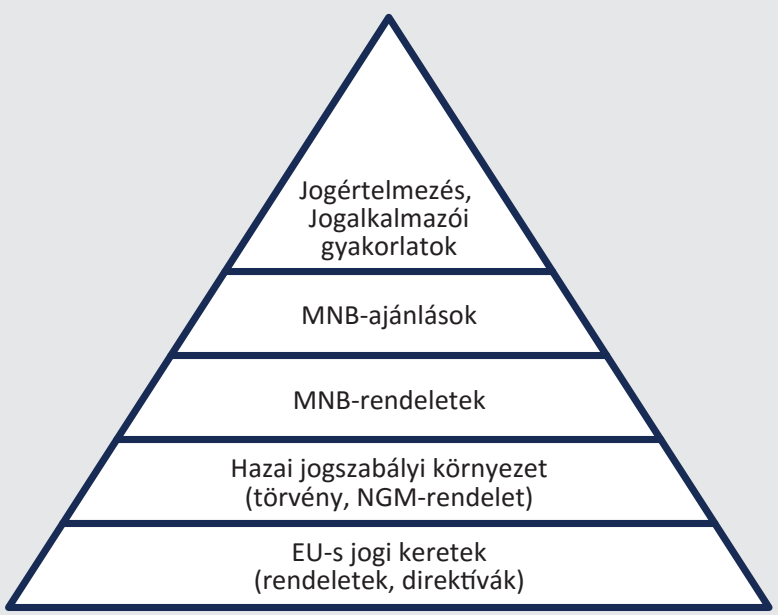

Forrás: MNB (2017)

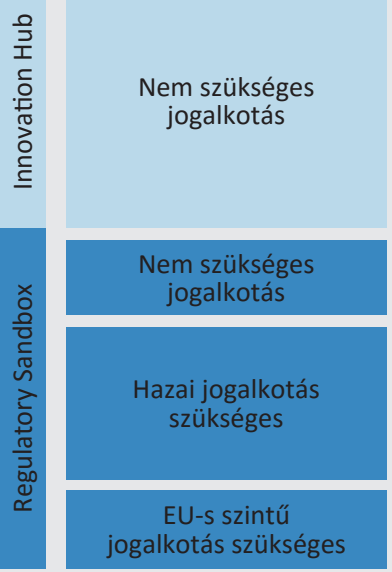

jogalkotás szükséges

\section{Konklúzió}

Mind a hazai FinTech-ökoszisztéma érdemi szereplőivel folytatott konzultációs folyamat, mind pedig a nemzetközi legjobb gyakorlatok számbavétele abba az irányba mutat, hogy a FinTech-innovációkkal kapcsolatos szabályozói optimum megtalálásának leghatékonyabb eszközei az Innovation Hub és a Regulatory Sandbox lehetnek (MNB 2017). Ezek a koncepciók alkalmasak arra, hogy bonyolult, érdemi jogalkotási terhet jelentő szabályozások „előre” megalkotása nélkül felderítsék, mely innovatív ötlet milyen piaci potenciált hordoz magában. Amennyiben egy innováció tartósnak és jelentős ügyfélelőny hordozójának bizonyul, úgy a koncepciók használatát követően a szabályozó a megfelelő információellátottság birtokában kezdheti meg a vonatkozó jogi keretrendszer implementálását.

A nemzetközi példák számbavétele ugyanakkor arra is rámutatott, hogy nem létezik általánosan hatékony, minden geopolitikai sajátosságot kielégítő uniformizált megoldás. A koncepciók kialakításakor minden esetben tekintettel kell lenni az adott ország pénzügyi közvetítő rendszerének sajátosságaira, a pénzügyi kultúra szintjére és a vonatkozó jogi keretrendszer egyedi megoldásaira. A külföldön hatékonyan 
működő megoldások egyszerű „lemásolása” tehát nem múködőképes, a nemzetközi legjobb gyakorlatok és a helyi sajátosságok mixtúrája eredményezheti egy hatékony koncepció létrejöttét.

\section{Felhasznált irodalom}

Aaron, M. - Rivadeneyra, F. - Sohal, S. (2017): Fintech: Is This Time Different? A Framework for Assessing Risks and Opportunities for Central Banks. Bank of Canada Staff Discussion Paper, 10.

Arner, D. W. - Barberis, J. N. - Buckley, R. P. (2016): The evolution of FinTech: A new postcrisis paradigm? UNSW Law Research Paper, No. 62.

ASIC (2009): Applications for relief. Regulatory Guide 51. http://download.asic.gov.au/ media/1238972/rg51.pdf. Letöltés ideje: 2018. február 27.

ASIC (2017): Testing fintech products and services without holding an AFS or credit licence. http://download.asic.gov.au/media/4420907/rg257-published-23-august-2017.pdf. Letöltés ideje: 2018. február 27.

BIS - FSB (2017): FinTech credit, market structure, business models and financial stability implications. http://www.bis.org/publ/cgfs_fsb1.pdf. Letöltés ideje: 2018. február 10.

BIS (2018): Sound Practices, Implications of fintech developments for banks and bank supervisors. Basel Committee on Banking Supervision, February. https://www.bis.org/ bcbs/publ/d431.htm. Letöltés ideje: 2018. március 10.

BNM (2016): Financial Technology Regulatory Sandbox Framework. http://www.bnm.gov.my/ index.php?ch=57\&pg=137\&ac=533\&bb=file. Letöltés ideje: 2018. február 15.

Bower, J. - Christensen, C. (1995): Disruptive Technologies: Catching the Wave. Harvard Business Review, January-February.

Christensen, C. M. (1997): The innovator's dilemma: when new technologies cause great firms to fail. Harvard Business School Press (edit), Boston, Massachusetts, USA.

Deutsche Bundesbank (2017): The role of banks, non-banks and the central bank in the money creation process. Deutsche Bundesbank Monthly Report 13. https://www.bundesbank.de/ Redaktion/EN/Downloads/Publications/Monthly_Report_Articles/2017/2017_04_money_ creation_process.pdf?_blob=publicationFile. Letöltés ideje: 2018. március 12.

DNB (2016): More room for innovation in the financial sector. https://www.dnb.nl/ en/binaries/More-room-for-innovation-in-the-financial\%20sector_tcm47-361364. pdf?2017072902. Letöltés ideje: 2018. február 15. 
DNB (2017): Regulatory sandbox honlapja. https://www.dnb.nl/en/supervision/ innovationhub/maatwerk-voor-innovatie-regulatory-sandbox/. Letöltés ideje: 2018. február 27.

EBA (2017): Discussion Paper on the EBA's approach to financial technology (FinTech). https://www.eba.europa.eu/-/eba-publishes-a-discussion-paper-on-its-approach-tofintech. Letöltés ideje: 2018. február 27.

EBA (2018): The EBA's Fintech Roadmap. http://www.eba.europa.eu/-/eba-publishes-itsroadmap-on-fintech. Letöltés ideje: 2018. február 27.

EC (2017): FinTech: A more competitive and innovative European financial sector. European Commission Consultation Document. https://ec.europa.eu/info/sites/info/files/2017fintech-consultation-document_en_0.pdf. Letöltés ideje: 2018. március 12.

EC (2018): FinTech Action plan: For a more competitive and innovative European financial sector. European Commission. https://ec.europa.eu/info/publications/180308-action-planfintech_en. Letöltés ideje: 2018. március 20.

EKB (2017a): Consultation on guides concerning the assessment of licence applications and fintech credit institution licence applications. https://www.bankingsupervision.europa.eu/ press/pr/date/2017/html/ssm.pr170921.en.html. Letöltés ideje: 2018. február 27.

EKB (2017b): Digital na(t)ive? Fintechs and the future of banking. https://www.ecb.europa.eu/ press/key/date/2017/html/sp170327_1.en.html. Letöltés ideje: 2018. február 27.

European Parliament (2017): Report on FinTech: The influence of technology on the future of the financial sector. Plenary Sitting. http://www.europarl.europa.eu/sides/getDoc. do?pubRef=-//EP//TEXT+REPORT+A8-2017-0176+0+DOC+XML+VO//EN. Letöltés ideje: 2018. február 10.

EY (2016): Transforming talent, The banker of the future. Global banking outlook 2016.

FCA (2015a): Regulatory sandbox honlapja. https://www.fca.org.uk/firms/regulatorysandbox. Letöltés ideje: 2018. február 27.

FCA (2015b): FCA honlapja. https://www.fca.org.uk/firms/authorisation. Letöltés ideje: 2018. február 27.

FSB (2017): Financial Stability Implications from FinTech: Supervisory and Regulatory Issues that Merit Authorities' Attention. 27 June. http://www.fsb.org/wp-content/uploads/ R270617.pdf. Letöltés ideje: 2018. február 10.

Gartner (2017): Research Methodologies: Gartner Hype Cycle. https://www.gartner.com/ technology/research/methodologies/hype-cycle.jsp. Letöltés ideje: 2018. március 12. 
He, D. - Leckow, R. B. - Haksar, V. - Mansini-Griffoli, T. - Jenkinson, N. - Kashima, M. Khiaonarong, T. - Rochon, C. - Tourpe, H. (2017): Fintech and Financial Services: Initial Considerations. IMF Discussion Note, SDN/17/05. https://www.imf.org/en/Publications/ Staff-Discussion-Notes/Issues/2017/06/16/Fintech-and-Financial-Services-InitialConsiderations-44985. Letöltés ideje: 2018. február 15.

KPMG (2018): The Pulse of Fintech - Q4 2017. https://assets.kpmg.com/content/dam/kpmg/ xx/pdf/2018/02/pulse_of_fintech_q4_2017.pdf. Letöltés ideje: 2018. március 12.

Lee, D. K. Ch. - Teo, G. S. (2015): Emergence of FinTech and the LASIC Principles. Journal of Financial Perspectives, 3 (3), 1-26. Research Collection Lee Kong Chian School of Business. https://doi.org/10.2139/ssrn.2668049

MAS (2016): FinTech regulatory sandbox guidelines. http://www.mas.gov.sg/ /media/ Smart\%20Financial\%20Centre/Sandbox/FinTech\%20Regulatory\%20Sandbox\%20 Guidelines.pdf. Letöltés ideje: 2018. február 15.

McKinsey \& Company (2016): FinTechnicolor: The New Picture in Finance. http://www.theblockchain.com/docs/FinTechnicolor-The-New-Picture-in-Finance\%20-\%20Mckinsey.pdf. Letöltés ideje: 2018. február 10.

MNB (2017): Innováció és stabilitás, FinTech körkép Magyarországon. Konzultációs dokumentum. Magyar Nemzeti Bank https://www.mnb.hu/letoltes/konzultaciosdokumentum.pdf. Letöltés ideje: 2018. február 10.

Nagy Márton - Vonnák Balázs (2014): Egy jól müködő magyar bankrendszer 10 ismérve. https://www.mnb.hu/letoltes/egy-jol-mukodo-magyar-bankrendszer-10-ismerve.pdf. Letöltés ideje: 2018. február 15.

Nicoletti, B. (2017): The future of FinTech, Integrating Finance and Technology in Financial Services. Palgrave Macmillan.

Philippon, T. (2016): FinTech Opportunity. NBER Working Paper, No. 22476. https://doi.org/ $10.3386 / \mathrm{w} 22476$

Stevenson, B. - Wolfers, J. (2011): Trust in public institutions over the business cycle. The American Economic Review, 101(3): 281-287.

WEF (2016) The Complex Regulatory Landscape for FinTech. World Economic Forum http://www3.weforum.org/docs/WEF_The_Complex_Regulatory_Landscape_for_ FinTech_290816.pdf. Letöltés ideje: 2018. február 15.

Zetzsche, D. - Buckley, R. P. - Arner, D. W. - Barberis, J. N. (2017): Regulating a Revolution: From Regulatory Sandboxes to Smart Regulation. European Banking Institute (EBI) Research Paper Series, 2017-11. https://doi.org/10.2139/ssrn.3018534 